\title{
The value-motivational structure of the innovativeness of young students
}

\author{
Olga B. Mikhailova \\ Peoples' Friendship University of Russia, Moscow, Russia \\ Corresponding author. E-mail: olga00241@ya.ru
}

The study of personal qualities' development and the peculiarities of value-motivational aspects in groups with various manifestation levels of these qualities are of particular interest for contemporary researchers as well as for practicing psychologists who develop psychotechnologies aimed at personal value-motivational sphere management.This article suggests new approaches for analyzing and studying value-motivational aspects of personal activity, predetermining innovation activity. It also provides an analysis of a comparative empirical study that evolves value-motivational characteristics in students with various innovativeness levels.

The author submits a detailed theoretical analysis of innovation behavior based on manifestations of personal value-motivational activity. Resulting from the given theoretical analysis, a suggestion is made that the manifestation and development of personal potential is determined by values and motives. Personal innovation potential is regarded as an effective combination of various activity forms, and innovativeness is a personal quality that is manifested by a form of effective activity. Currently, psychologists are highly interested in evolving value-motivational structure of personal innovativeness.

The given article discusses the results of an empirical study aimed at revealing value-motivational peculiarities of students in groups with various levels of innovativeness manifestations. Indicative peculiarities of value-motivational characteristics are revealed in groups with low, middle and high levels of innovative qualities. Furthermore, gender differences in innovativeness manifestation and value-motivational characteristics of this quality in young men and women are thoroughly described.

New data concerning the personal and gender specifics of the value-motivational sphere and innovativeness manifestation in young adults are presented using a thoroughly described research strategy as well as results substantiation.

Keywords: innovativeness, innovative potential, value-motivational sphere of innovative personality. 


\section{Introduction}

In our current society, the study of problems of demonstrating individual creativity has determined the necessity of creating new forms of management in personality development. To determine boundaries between personal success, effectiveness and efficiency, new leaders have emerged, whose activity can be beneficial and harmful to themselves and society. The prospect of psychological trends in character research is attributed to the identification of youth's value-motivational aspects of behavior and activities. Additionally, effective implementation of sociopsychological activity control technologies for the socio-economic development of society is involved as well.

Russian and foreign scientists have indicated common psychological activities of an individual as idiosyncrasy markers (Golichenko, 2004). The success of self-fulfillment is determined by a set of personal qualities that enable a person to achieve effective results. The phenomenon of self-fulfillment, including educational and professional activities, is inextricably linked to self-development and the active management of personal resources. One of the markers that characterize the social performance of self-fulfillment is the innovativeness of a personality.

An outstanding psychologist, Nebylitsin, defines a general mental individual activity as a psychological idiosyncrasy characteristic: "Mass action means a bundle of personality traits that predetermine primary individual needs in effective factuality acquisition. Such a drive state can be presented either in mental, motor (including speech ability) or social (communication) contexts. Accordingly, a number of mass action types can be singled out" (Nebylitsyn, 1976, p. 251). Each activity type has a "rather complicated multifactorial structure and various forms of psychological manifestations" (Nebylitsin, 1976, p. 241). According to Nebylitsin's findings, the most current personality analysis trends are as follows: 1) the activity is considered to be an act of "self-expression" and an arrangement of initiation and self-actualization; 2 ) the activity is regarded to be an arrangement of the effective acquisition and reality transformation (i.e., it is viewed in a close mutual connection with the productivity of cooperation with the environment); 3) the activity comprises a dynamic procedural aspect; 4 ) the activity represents a personal aspect, which is determined by relationships and motivations of the individual, who manages its direction, quality and level; and 5) the qualitative features of individual activity are determined by its dominant view and expressed in a definite form (Krupnov, 1996).

Consequently, contemporary personality psychology regards mental activity as a human activity characteristic. The activity can be viewed as a valuable way of modeling, structuring and actualizing communication and conduct by a personality. The activity is a characteristic of performance with an independent immediate power. It is expressed in free, conscious, internally necessary work. A bundle of socio-psychological traits and qualities determine activity and lets a personality manage it by means of values and motives. Consequently, socially oriented valuemotivational creative activity can be considered (Mikhailova, 2010).

Social and personal values stand out as a human activity mark that allows for estimating and using activity in relation to reality. The dualities of truth and lying, admissible and forbidden, and fair and unfair play an important role in a person's 
construction of demands and motives, idiosyncrasies and activities. The individual does not always apprehend values and does not lose the regulatory influence on personal enhancement (Zinchenko, 2010).

The system of values constructs individual values and motives. Value-objective norms and mindsets influence the development of the motives that predetermine individual effectiveness.

Innovative conduct is substantially predetermined by the peculiarities of values and motives, the structure of which has not yet been studied. The search for differences and relationships between the value-motivational system and innovative manifestations will reveal the system of value-motivational characteristics (Mikhailova, 2012).

Innovative and initiating causes of behavior are the foundation of innovative activity organizations and are correlated with the study of individual potential. The concept of human potential is characterized by various trends of its study: social and organizational, economic, social and environmental, and existential. The notions of psychophysiological capacity (V.I. Medvedev, G.M. Zarakovsky), professional and personal potential (V.N. Markov), adaptive potential (A.G. Maklakov), leadership potential (A.N. Zankovsky) innovative potential (V.E. Klochko, E.V. Galazhinsky), and intellectual potential (B.G. Yudin) have been described.

The common feature of all of the above-mentioned approaches is that personal potential is determined by means of successful self-realization in a particular activity and resolved into a set of abilities and skills, as well as by the fulfillment of this activity. The attributive schemes and strategies are the key variables for understanding the nature of personal potential as a self-regulation potential (Leontiev, 2001).

The attributive schemes are developed under the influence of personal experience. This notion is called the representation system of ideas about the world structure; its orientational basis impacts personal decisions, activities and aims. The strategy is a stable focus of our conduct or a sustainable method of behavior that is consciously selected and subjected to deliberate changes. It is a stable mark for managing its own voluntary action. According to A.D. Leontiev's theory, the structure of personal potential consists of the following components: optimism; hardiness; personal self-regulation; self-efficacy; ambiguity tolerance; control over action; reflectivity; and subjective vitality (vital power) (Leontiev, 2011). Each of the above mentioned features is a rather complex multifactorial quality and involves comprehensive theoretical and empirical analysis.

Studying personal potential, instead of the human assets research problem, provides an opportunity to define the following perspective research trends: 1) the nature of the variables characterizing personal potential; 2) the methodology of grounding and empirical definition of the dominant components; 3 ) the research strategy and research methods tool set; 4) the establishment of a new diagnostic tool set; 5) technology support elaboration and the formation of a personal development potential at various ages; and 6) the development and maintenance of personal psychological assets (psychological resources).

It is advisable to use the systemic and functional approach to solve the formulated perspective trends of personal potential research. This trend in the study of personality originated from the following Russian psychological theories: the inseparability of dynamic, meaningful and productive mental activity aspects 
(Brushlinsky, 1978; Nebylitsyn, 1976, Rubinstein, 1973, Krupnov, 1990, etc.), the unity of the personal and individual subject composition (Ananiev, 1980; Golubeva, 1983, 1993; Lomov, 1984, Merlin, 1985, etc.), and the systemic nature of the personal relationship (Abulkhanova-Slavskaya, 1991; Bodalev, 1988; Myasischev, 1960, Krupnov, 2006).

S.L. Rubinstein indicated that the systemic nature of personal traits represents the fusion of images of thoughts, feelings, and impulses in unity and interpenetration with the objective consecution and the results of actions. Nebylitsyn's theory was based on the study of the connections between meaningful, dynamic and productive aspects. Ananev suggested that individual personality traits comprised not only presentational relationships but also the methods of its fulfillment, motives, and emotional, intellectual and productive characteristics. Bodalev claims that personality traits are the integration of private relationships to various events. This integration represents the unity of knowledge, experience and behavior. The analysis of theoretical statements indicates that personality traits are multifactorial as opposed to a single interpretation (Mikhailova, 2013).

In the early 1980s, the Russian academician Alexander Ivanovich Krupnov introduced a well-founded, systemic and dispositional approach to the study of personality and its traits (Krupnov, 2006). According to this systemic and dispositional approach, innovative personal potential can be considered to be a highly effective combination of personal activity forms that are required for practical innovative fulfillment.

Innovativeness is viewed as a further creativity staging point, a benchmark of immediate assessment and a practical embodiment of innovations, which is a particular socio-organized practice. Therefore, innovativeness can be defined as a person's ability to understand, receive, socially estimate, spread, implement and use innovations. Innovativeness can be fully expressed in business activity (Mikhailova, 2012).

The bases of innovative activity development are the values and motives of an individual. Consequently, the value-motivational system actively determines personal innovativeness by acting as both a prerequisite and a blocker.

The value-motivational relationship with innovative activity is defined as a set of internal necessary and available external conditions and socially established values.

The system of values is the "basis" of a relationship with the world. Values can be considered to be relatively stable, socially conditioned, selective and conscious attitudes towards unspiritual and spiritual matter in human society. The motivational sphere is traditionally indicated in various activities as a link that makes action purposeful and determines personal potential. Problems of motivation and motives have been widely covered in the works by Russian and foreign psychologists: V.G .Aseyev, E.P. Ilyin, V.I. Kovalev, K. Levin, A.N. Leontiev, G.F. Lomov, A. Maslow, V.E. Milman, J. Nyutten, S. L. Rubinstein, B.A. Sosnovsky, H. Heckhauzen, etc. (Sovetova, 2000).

The research and development of value-motivational activities in innovative participants is essential for every sphere of professional activity. The transition from a traditional system to innovative fulfilment requires new methods of solving 
problems. This approach implies a serious stereotype breakage that is associated with changes in the approach to the objectives, forms and methods of activity.

The indicators of motivational readiness for innovativeness are the following (Koptyaeva, 2009):

Interest expression in innovation and its dynamics - a positive attitude towards innovation, and the desire to be involved; experience of the positive emotional states regarding innovation, striving desire to assess one's own professional and personal experience from the point of innovation; positive attitude towards the perspectives of innovation;

- Self-actualization maturity motive - awareness of one's own capabilities, the necessity to improve oneself, growing more confident;

- Overcoming difficulties maturity motive - awareness of one's individual insufficient achievements and the desire to improve them; understanding of one's problems and independence in its solving them and taking responsibility for them.

The problem of innovative activity motivation should be considered a problem of acquiring the adequate personal meaning of professional activities. Due to the mismatch of motives, discomfort results in the labor deprivation of personal selfdevelopment and creativity. It turns from a personal value to the means of one's livelihood. The management development of personal potential is very important to achieve a creative and a productive labor value in a modern practice. Studying the needs, interests and values of youths in an educational environment should influence new generations of motive systems. Personal activity must be expressed using constructive behavior and activities. Consequently, if personality development is properly managed, the value-motivational activity is expressed in new activities.

In psychological studies, activity is considered to be a specific human form of an active attitude towards the world. The essence of that form consists of a reasonable change and world transformation based on the development of available forms of culture. Innovative activity aims to transform existing forms, including the methods of professional activities and awareness of them and the creation of new aims as well as the means of realization. Therefore, the result of this activity leads to an expectation of the progress of society. In the studies by Anokhin, Lomov, and Leontiev, the psychological analysis of activity reveals its structure. The activity is viewed as a dynamic action system, arising and reorganizing under the controlling influence of complicated motivational interactions.

According to Lomov, the main activity factors are the following: motive, purpose, plan, current information processing, immediate image (and a conceptual model), decision-making, results checking and corrective actions (Lomov, 1984).

Because multiple relationships with the environment are presented in a relatively stable personal motivational sphere, any activity, as well as innovativeness, usually correlates with more than one motive. Therefore, it becomes multimotivational.

As most motives are not recognized, except conscious motives, and are hidden from other people, one has to answer the actual questions: which direction, which actions, and which orientation are used in the context of value-motivational personality traits? 
The motivational component of innovative activities needs to be considered in two ways: the perspective of professional motivation in the overall structure of motives and the estimation of the individual concern to changes (i.e., susceptibility features that determine the content of creative professional directivity after identifying needs in innovations) (Mikhailova, 2012).

The diagnosis of the value-motivational innovative activity and elaboration of development activity programs are fundamental conditions of innovative personality potential improvement and self-fulfillment in professional activities (Lebedeva, Bushina, Cherkasova, 2013).

Consequently, the definition of innovative development in young students and the identification of the similarities and differences among value-motivational aspects are important for obtaining new data on value-motivational personality traits.

\section{Method}

\section{Participants}

The article provides an analysis of the characteristics in the value-motivational structure in groups with various levels of innovative manifestations. One-hundredforty students studying at the Faculty of Economics (Peoples' Friendship University of Russia) were involved in the empirical research. Their ages ranged from 19 to 21 years old. The following diagnostic methods were provided: "The scale of innovative personality traits self-assessment" (N.M. Lebedeva, A.N. Tatarko); "Motivational personality structure questionnaire" (E. Milman); and Real structure of personal value orientations questionnaire (C.C. Bubnova).

\section{Materials}

To determine the innovativeness parameters, a self-evaluation scale of the innovative qualities in a personality was used (N.M. Lebedeva, A.N. Tatarko). This questionnaire was designed to measure attitudes towards innovation. The questionnaire consists of 12 statements with which the respondents could compare themselves (possible answers - "Not like me at all", "Not like me", "A little like me", "Like me", "Very much like me"). According to the responses, the general level of innovativeness (index of innovation) is revealed.

For the qualitative analysis of innovativeness, questions of particular subscales were used:

1) Creativity: 4, 5, 8, and 10.

2) Risk for success: $3,6,11$, and 12

3) Focus on the future: 1, 2, 7, and 9.

Indicators on all of the scales and the personal innovativeness index ranged from 1 to 5 points.

To determine value orientations, we used the technique "Diagnostics of the actual structure of personal value orientations" by S.S. Bubnova, which is designed to study the implementation of personal value orientations in real life. The technique contains 66 closed questions with which the respondent can agree or disagree (pos- 
sible answers - "Yes" or "No"). The responses reveal the prevailing values of a respondent. The technique includes 11 scales. The degree of each component in the multistructural personal value orientations representation is determined by using a key represented in an answer form. Accordingly, the number of positive responses in all eleven columns was calculated (described below).

To determine the motivational structure, the questionnaire of the personal motivational structure by Milman was used to identify the predominant types in human motivation. The technique also identifies some steady personal trends: general and creative activity, desire to communicate, comfort and social status maintenance and others. Based on all of the responses, a judgement on working (business) and the everyday orientation of an individual can be made. The questionnaire consists of 11 statements relating to life aspirations and particular aspects of a person's lifestyle and includes the following types of motivation:

1. "Life maintenance"

2. "Comfort"

3. "Social status"

4. "Communication"

5. "General activity"

6. "Creative activity"

7. "Social utility"

\section{Results}

As a result of research conducted using the questionnaire "Self-evaluation scale of personal innovative qualities" (N.M. Lebedeva, A.N. Tatarko), student groups with high (20\%), middle (59\%) and low (18\%) levels of innovativeness were distinguished. Further correlative and factor analyses were used to describe the peculiarities of value-motivational aspects in groups with various levels of innovativeness. The calculations were made using the computer programs Statistica and Statgraphics.

Data factor analysis showed that the group with a low level of innovativeness focused on values, such as the search for pleasure (0.76), love (0.88), recognition and respect of people and their impact on others (0.75) and social activity for achieving positive changes in society (0.79).

The group of students with a low level of innovativeness focused on the future and valued a high level of material well-being (0.85), communication (0.66) and high social status and people management $(-0.62)$. The leading motives of the group were overall activity (0.71) and everyday motivation (0.68) (table 1 ).

The results of the factor analysis of the group with an average level of innovativeness revealed the following structure of values - pastime and recreation (0.65); high material well-being (0.71); search for and enjoyment of the beautiful (0.72), help towards and compassion for others (0.69); love (0.68); new knowledge about the world, nature and man (0.75); high social status and people management (0.81); recognition and respect of people and their impact on others (0.90); and social activity to achieve positive changes in society (0.92). Although this group did not focus on the future and the development of their creative potential, the system of 
values and future motivational aspects were not clear. Furthermore, the structure of the dominant motives was not revealed.

Table 1. Factor analysis of the values and motives of the group with a low level of innovativeness

\begin{tabular}{|c|c|c|c|c|}
\hline & \multicolumn{3}{|c|}{ Factors } \\
\hline & & 1 & 2 & 3 \\
\hline \multirow{3}{*}{ 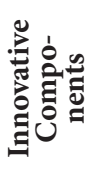 } & Creativity & -0.51 & -0.4 & 0.23 \\
\hline & Risk for success & 0.53 & 0.19 & 0.34 \\
\hline & Focus on the future & 0.53 & 0.73 & 0.17 \\
\hline \multirow{11}{*}{ 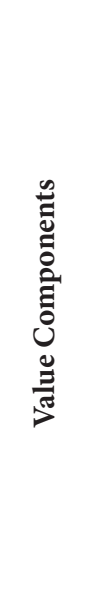 } & Pastime, recreation & 0.53 & -0.005 & 0.11 \\
\hline & High level of material well-being & 0.04 & 0.85 & -0.24 \\
\hline & Search of pleasure & 0.76 & 0.09 & 0.103 \\
\hline & Help towards and compassion for others & 0.56 & 0.42 & -0.43 \\
\hline & Love & 0.88 & 0.01 & -0.006 \\
\hline & New knowledge about the world, nature and man & 0.18 & -0.44 & -0.26 \\
\hline & High social status and people management & 0.59 & -0.62 & 0.07 \\
\hline & $\begin{array}{l}\text { Recognition and respect of people and the impact } \\
\text { on others }\end{array}$ & 0.75 & 0.502 & -0.17 \\
\hline & $\begin{array}{l}\text { Social activity for achieving positive changes in } \\
\text { society }\end{array}$ & 0.79 & -0.48 & -0.06 \\
\hline & Communication & -0.009 & 0.66 & 0.23 \\
\hline & Health & 0.47 & -0.08 & -0.19 \\
\hline \multirow{9}{*}{ 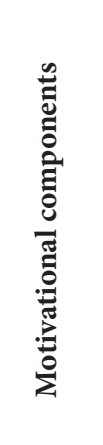 } & Life maintenance & -0.04 & 0.50 & -0.13 \\
\hline & Comfort & 0.24 & 0.11 & -0.52 \\
\hline & Social status & 0.29 & 0.31 & 0.34 \\
\hline & Communication & -0.03 & -0.53 & -0.23 \\
\hline & Overall activity & 0.23 & 0.49 & 0.71 \\
\hline & Creative activity & -0.30 & -0.45 & 0.03 \\
\hline & Social utility & -0.12 & 0.01 & 0.59 \\
\hline & Everyday motivation & 0.30 & 0.04 & 0.68 \\
\hline & Work motivation & 0.14 & 0.16 & -0.46 \\
\hline
\end{tabular}

In the group with a high level of innovativeness, the structure of value orientations was represented by indicators including new knowledge about the world, nature and man (0.81); love (0.74); high social status and people management (0.83); recognition and respect of people and their impact on others (0.81); and social activity to achieve positive changes in society (0.95).

This group of students focused on a future high level of material well-being (0.72), help towards and compassion for others, (0.65), search for and enjoyment of beautiful things (0.70), and recognition and respect of people and the impact on others $(0,81)$ 
The dominant motives and values were the drive for creativity (0.64) and health (0.78) (Table 2).

Table 2. Factor analysis of the values and motives of the group with a high level of innovativeness

\begin{tabular}{|c|c|c|c|c|}
\hline & & \multicolumn{3}{|c|}{ Factors } \\
\hline & & 1 & 2 & 3 \\
\hline \multirow{3}{*}{ 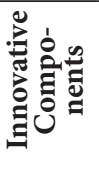 } & Creativity & -0.11 & 0.38 & 0.64 \\
\hline & Risk for success & -0.20 & 0.08 & -0.22 \\
\hline & Focus on the future & 0.38 & -0.73 & 0.002 \\
\hline \multirow{10}{*}{ 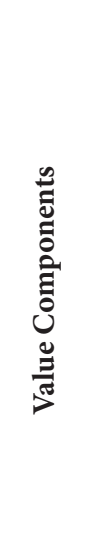 } & Pastime, recreation & 0.35 & 0.41 & -0.27 \\
\hline & High material well-being & 0.20 & 0.72 & 0.01 \\
\hline & Search for and enjoyment of the beautiful & 0.56 & 0.65 & 0.17 \\
\hline & Help towards and compassion for others & 0.47 & 0.70 & 0.16 \\
\hline & Love & 0.74 & 0.11 & 0.03 \\
\hline & New knowledge about the world, nature and man & 0.81 & -0.06 & -0.20 \\
\hline & High social status and people management & 0.83 & 0.13 & 0.06 \\
\hline & $\begin{array}{l}\text { Recognition and respect of people and the impact on } \\
\text { others }\end{array}$ & 0.50 & 0.81 & 0.06 \\
\hline & $\begin{array}{l}\text { Social activity for achieving positive changes in } \\
\text { society }\end{array}$ & 0.95 & 0.07 & -0.04 \\
\hline & Communication & 0.05 & 0.54 & 0.42 \\
\hline \multirow{10}{*}{ 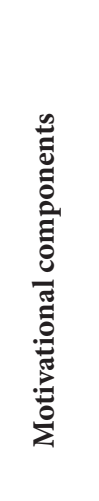 } & Health & 0.04 & 0.34 & 0.78 \\
\hline & Life maintenance & 0.01 & -0.14 & 0.46 \\
\hline & Comfort & -0.06 & 0.48 & -0.54 \\
\hline & Social status & 0.10 & -0.45 & 0.16 \\
\hline & Communication & 0.51 & 0.06 & -0.001 \\
\hline & Overall activity & -0.19 & -0.08 & 0.57 \\
\hline & Creative activity & 0.12 & 0.11 & 0.54 \\
\hline & Social utility & -0.53 & -0.18 & -0.18 \\
\hline & Everyday motivation & 0.03 & 0.05 & 0.55 \\
\hline & Work motivation & -0.48 & 0.27 & -0.02 \\
\hline
\end{tabular}

\section{Discussion}

The self-evaluation of innovative qualities identified groups with high, medium and low levels of innovativeness. The most numerous group of students had an intermediate level of innovativeness. This result is explained by the insufficient development of the innovative potential of students.

Based on a comparative analysis of the value-motivational characteristics of student's innovativeness using the Kruskel-Wallis test and a correlational and factor analysis, the significant value-motivational characteristics were revealed. There was a distinctive feature in each of the groups: 
- The values of the respondents with a low level of innovativeness contained: a pleasant occupation and level of recreation and a commonsense motivation, although it was focused on high social status and people management;

- Respondents with an average level of innovativeness identified such valuemotivational characteristics as survival, comfort, and communication; in the motivational structure, commonsense motivation, working motives and social utility motives, and total activity dominated.

- In the group of respondents with a high level of innovativeness, the motives of creative activity and total labor activity were the dominant value orientations.

As a result of the factor analysis, three groups of factors constituting the valuemotivational characteristics of students' innovativeness were identified. The first group of factors was the structure of values in each group. The second group of factors included value-motivational features, with a focus on the future, and the third group of factors determined the dominant motives.

In the group of students with a low level of innovativeness, the following characteristics were dominant: enjoying beauty, love, acceptance and respect of people and the impact on others to achieve positive change in society. When focusing on the future in this group, the following were associated with wealth, high social ranking and people management. The leading motives of the group were general activity and commonsense motivation.

The results of the factor analysis in the group with an average level of innovativeness revealed the next diverse structure of values: enjoying occupation, recreation, and welfare; search and enjoying beauty; help and mercy for others; love; new knowledge in the world, nature, and humans; high social status and people management, recognition and respect of people and their impact on others; and social activity to achieve positive change in society. The group was not focused on the development of their creative potential in the future, and the system of values and motivational aspects and the structure of the dominant themes were not defined in the study. The obtained data indicate the diversity and unclear structure of the value-motivational process.

In the group with a high level of innovativeness, the following value orientations were discovered: new knowledge of the world, nature, and humans; high social status and people management; recognition and respect of people and their impact on others; and social activity to achieve positive change in society. Orientation towards the future was associated with welfare, help and compassion for others, finding and enjoying beauty, recognition and respect of people and the impact on others. The dominant motives and values were the tendency for creativity and health. In the student group with a high level of innovativeness, the value-motivational characteristics were in their formative stage, but they had a clear structure.

The findings were further subjected to a gender analysis of students' innovativeness. Boys showed better results on the innovativeness index, whereas the creativity index in the girls' sample group was higher. Both sample groups were ready to take risks for success. The female students' sample group was more future-oriented than the male group. 
The results of the correlation analysis demonstrated that the young men were willing to take risks and assist and show mercy to others. The boys were focused on overall activity and social utility in the future. The girls' dominant innovative manifestations were creativity, but they were focused on social activity and making a positive difference in society in the future. Generally, the study found that boys were more willing to take risks and that girls were more creative, but both sample groups wanted to achieve social benefits and positive change in society in the future.

Based on the factor analysis, the value-motivational structure of students' innovativeness was divided into 3 groups of factors: the factors of the value-motivational structure, the factors of value-motivational characteristics in the future and motivational factors of value-risk characteristics for success.

The following gender differences were present in all 3 groups of factors:

- The value-motivational innovativeness structure of the boys had more detailed values and motives, which were equally represented as hedonistic and social components: pleasant occupation, recognition and respect of the people and the impact on others and comfort, social status, communication, motivation and social utility. In the girls, more pronounced motivational components of total activity dominated: creative activity, social utility and work motivation;

- The value-motivational characteristics of the girls' future demonstrated both hedonistic values (pleasant occupation, recreation, comfort) and social values and motives (communication, commonsense motivation, social status). The boys showed more pronounced social values and motives for the future, such as: social activities to achieve positive changes in society, communication, total activity, creative activity, and social utility and work motivation;

- Regarding the value-motivational risk characteristics for success, the boys were willing to take risks for the sake of wealth and high social status and to provide assistance and charity, and the girls were willing to take risks and be socially active to achieve positive changes in society.

In summary, the tendencies of the hedonistic and exploitative characteristics are seen in the value-motivational structure of students with a low level of innovativeness. Because of the demonstrated values of pleasant occupation and recreation, the focus on high social status and people management was explored. Consequently, there was a tendency to achieve status and people management without the desire for creative activity. These characteristics are alarming symptoms. It is evident that this group of students requires particular attention. The psychological services at a university and the faculty should do their best to develop the students' value-motivational activity. There is a risk that individuals with low innovativeness freeload on more developed personalities and exploit the potential of a more creative society.

The group of students with an average innovativeness level showed the most diverse palette of value orientations. They demonstrated both hedonistic and valuemotivational aspects of social activity and creativity equally. This tendency is due to the age features of youth development, when some value orientations and motives 
are actively replaced by others. Generally, the value-motivational sphere is unstable and prone to serious changes due to the influence of society. The socio-economic trends of society will substantially impact the structure of the value-motivational sphere and the development of personal innovativeness. These findings suggest that the sample group of students with an average level of innovation have an uncertain motivational structure. This finding confirms the need for assessing the psychopedagogical influence on youth motivational development.

In the group with a high level of innovativeness, as well as in the group with a low level of innovation, the values of high social status and people management were revealed. Unlike the first group, the values in the second groups varied and included new knowledge of the world, nature, and humans; recognition and respect of people and their impact on others; and social activity to achieve positive change in society. However, the motivational structure was expressed only by creative activity. The results of the study discovered the lack of a clear motivation for the particular activity in which one can apply it. There are serious concerns that the motives of creative activity can be transformed into other necessities in a particular activity that is not supported by motives of social significance. It is very important that the psychological services at a university and the faculty understand the valuemotivational activity development of a person. Psychological support is required for the groups of students with various levels of innovativeness, as well as fir students with a high level of innovation.

\section{Conclusion}

In the search for socio-psychological and socio-economic development priorities in modern society, the perspectives of psychological research are aimed at identifying the value-motivational personality characteristics and the formation of youth creative activity. The values cultivated by society give rise to a new generation of individuals who are guided by the community's values. The value-motivational youth activity is the basis of society's progress and well-being.

The results of this study are of particular interest for practicing psychologists who can broaden the sphere of investigating the personal value-motivational structure and determining the basic methods of psychocorrective work in effective human capital asset development. Determining the value-motivational innovative activity and increasing personal developmental programs are the fundamental bases for innovative personality potential improvement and self-fulfillment in a professional career.

\section{References}

Golichenko, O. G. (2004) Rossiyskaya innovatsionnaya sistema: Problemy razvitiya [Russian innovative system: The problems of development]. Vestnik Ekonomiki [Economy Bulletin], 12, $16-35$.

Koptyaeva, O. N. (2009). Motivatsionnaya gotovnost' pedagogov $k$ innovatsionnoy deyatel'nosti [Teachers' motivational willingness for the innovative activity]. (Unpublished doctoral dissertation). Yaroslavl, Russia: Yaroslavl State Pedagogical University.

Krupnov, A. I. (2006). Sistemno-dispozitsionnyy podkhod k izuchenie lichnosti i ee svoystv [Systemic and dispositional approach to personal study and its characteristics]. Vestnik 
RUDN, seriya "Psikhologiya i pedagogika" [Peoples Friendship University of Russia Bulletin. Psychology and Pedagogy], 1(3), 63-72.

Krupnov, A. I. (1996). Problema aktivnosti i tselostnaya kharakteristika individual'nosti cheloveka [The problem of activity and comprehensive personal characteristics. In V.D. Nebylitsin. Zhizn' i nauchnoe tvorchestvo [V.D. Nebylitsin. Life and scientific creativity] (pp. 281-291). Moscow: Ladomir.

Lebedeva, N. M., Bushina, E. V., \& Cherkasova, L. L. (2013). Tsennosti, sotsial'nyy kapital i otnoshenie $\mathrm{k}$ innovatsiyam [Values, social capital and attitude to innovations].Obshchestvennye nauki i sovremennost [Social sciences and modernity], 4, 28-41.

Leontiev, D. A. (2001). Lichnostnaya zrelost kak oposredstvovanie lichnostnogo rosta [Personal Maturity as a Mediation in Personal Development]. In I.A. Petukhova (Ed.), Kulturno-istoricheskaja psihologija razvitija [Cultural-historical psychology of development] (pp. 154161). Moscow: Smysl.

Leontiev, D. A. (Ed.). (2011). Lichnostnyy potentsial: Struktura i diagnostika [Personal potential: Structure and diagnosis]. Moscow: Smysl.

Lomov, B. F. (1984). Metodologicheskie i teoreticheskie problemy psikhologii [Methodological and theoretical problems of psychology]. Moscow: Nauka.

Mikhailova, O. B. (2012). Innovatsionnyi potentsial lichnosti: diagnostika i razvitiye [Innovative Capacity of a Personality: Diagnostics and Development]. Moscow: Institute MIRBIS.

Mikhailova, O. B. (2010). Metodologicheskie osnovy issledovaniya innovatsionnogo potentsiala lichnosti [Methodological Basis of Personal Innovative Capacity Research].Vestnik Universiteta GUU [State Managerial University Bulletin], 21, 71-75.

Mikhailova, O. B. (2012). Vidy aktivnosti kak determinanty razvitiya innovatsionnogo potentsiala lichnosti [Types of activity as personal innovative potential determiner]. Vestnik RUDN. Seriya: Psikhologiya i pedagogika [[People's Friendship University of Russia Bulletin. Psychology and Pedagogy],4, 35-44.

Mikhailova, O. B. (2013). Psikhologiya stanovleniya innovatsionnogo potentsiala lichnosti: monografiya [Psychology of personal innovative potential development]. Moscow: People's Friendship University of Russia.

Nebylitsin, V. D. (1976). Psikhofiziologicheskoe issledovanie individual'nykh razlichiy [Psychophysiological research of individual differences] Moscow: Nauka.

Sovetova, O. S (2000). Osnovy sotsialnoy psikhologii innovatsiy [The basics of social psychology of innovations]. Saint Petersburg: Saint Petersburg State University Press.

Zinchenko, V. P. (2010). Soznanie i tvorcheskiy akt [Consciousness and creative act]. Moscow: Yazyki slavyanskikh kultur.

Original manuscript received June 17, 2014

Revised manuscript accepted February 17, 2015

First published online March 31, 2015 